\title{
China's Direct Investment Efficiency toward the Countries along the Belt and Road
}

\author{
Xiao Bing Jiang* and Li Ming Liu \\ Department of Economics, Xidian University, 266 Xinglong Section of Xifeng Road, Xian, China
}

\begin{abstract}
With the all-round promotion of the "Belt and Road Initiative," China's investment in the countries along the line has gradually expanded, but its investment efficiency has been relatively low. Based on this, taking the panel data of 46 countries directly under the "Belt and Road" from 2006 to 2015 in China as an example, the paper uses a stochastic frontier model to evaluate the investment efficiency and its changes comprehensively. The research shows that the overall efficiency of China's investment in the countries along the line is not high, and In the meantime, the investment efficiency of our country along the line shows a slight downward trend during the period of investigation, and the rate of technological progress is the main factor restricting the investment efficiency. To this end, we should optimize investment structure and location selection, and strengthen the investment skills. Innovate in technology, construct a transnational knowledge network system, deepen capacity cooperation between the two sides and enhance the agglomeration of investment industries.
\end{abstract}

Keywords: Belt and road; Foreign direct investment; Investment efficiency; Location selection

\section{Introduction}

The "Belt and Road Initiative" strategy has created a new pattern of opening up to the outside world in a grand way to reshape the world economic pattern and has also greatly promoted the wave of OFDI and international capacity-building cooperation. 65 countries and regions covered by the "Silk Road Economic Belt" and the "21st Century Maritime Silk Road" are among the most potential areas in the world in terms of investment in China's infrastructure, capacity cooperation and modern service industries. On the basis of remarkable results achieved in cooperation, formally entered the stage of comprehensive promotion in 2015. Policy communication, facilities connectivity, trade flow, financial intermediation and people-to-people exchanges and communication are the main contents of the "Belt and Road Initiative" strategy and continue to promote China's direct investment in countries along the line. From 2008 to 2014, China's direct investment in countries along the "One Belt and One Road" grew rapidly, its direct investment flow increased from 41.43 billion US dollars to 13.6 billion US dollars, an average annual growth rate of $61.1 \%$, and investment in 49 Countries and regions, mainly to Singapore, Indonesia, the United Arab Emirates, Algeria and Russia and other countries [1]. In the future, with the acceleration of the construction of China Unicom, along with the deepening of capacity cooperation and the effective construction of financing platform, China will effectively promote direct investment in the "One Belt and Road" into the "fast track" for accelerated development. However, China still faces some prominent problems such as uneven distribution of investment area, slow upgrading of investment industry structure and prominent investment risks. Therefore, it probes deeply into the efficiency and trend of China's direct investment in key countries along the route, The Belt and Road "The sustainable development of investment has very important theoretical and practical significance.

\section{Establish a Model}

\section{The benchmark model}

Tingbergen first applied the gravity model to the field of international trade. In 1962, he proposed that "the bilateral trade flows between the two countries are positively related to their economic size and negatively related to the actual distance between them [2]." Later, empirical research by scholars applied it to the field of investment. Most studies show that the scale of bilateral investment is closely related to the economic scale, geographical distance and political system of the two countries, and the effect of the total economy is particularly significant [1].

With reference to the stochastic frontier gravity model, a benchmark model of investment is constructed using panel data from 2006 to 2015 .

$$
\ln O F D I_{i j t}=\beta_{0}+\beta_{1} \ln G D P_{j t}+\beta_{2} \ln G D P_{i t}+\beta_{3} \ln D i s t_{i j}+\omega_{i t}
$$

The classical stochastic frontier model comes from the production function. The expression of stochastic frontier model of panel data is:

$$
\begin{aligned}
& Y_{i t}=f\left(x_{i t} \beta\right) \exp \left(-u_{i t}\right) \exp \left(v_{i t}\right) \\
& y_{i t}^{*}=f\left(x_{i t}, \beta\right) \exp \left(v_{i t}\right) \\
& T E_{i t}=y_{i t} / y_{i t}^{*}=\exp \left(-u_{i t}\right) \\
& u_{i t}=[\exp [-\eta(t-T)]\} u_{i}
\end{aligned}
$$

Model (1) is the flow rate expression of China's direct investment in China during period t. Models (2) and (3) are respectively the expressions of actual output and frontier output of the first country at the period, The actual output and the frontier output of the country in period $t$; it is the natural factor that affects the output; it is the white noise error term and belongs to the non-system efficiency; it is the parameter vector; it is the non-efficiency disturbance term; (4) (5). It

*Corresponding author: Xiao-Bing Jiang, Department of Economics, Xidian University, 266 Xinglong Section of Xifeng Road, Xian, China, Tel: 862981891818; E-mail: 2237488682@qq.com

Received January 07, 2018; Accepted March 07, 2018; Published March 14 2018

Citation: Jiang XB, Liu LM (2018) China's Direct Investment Efficiency toward the Countries along the Belt and Road. J Glob Econ 6: 284. doi: 10.4172/23754389.1000284

Copyright: ( 2018 Jiang XB, et al. This is an open-access article distributed under the terms of the Creative Commons Attribution License, which permits unrestricted use, distribution, and reproduction in any medium, provided the original author and source are credited. 
Citation: Jiang XB, Liu LM (2018) China's Direct Investment Efficiency toward the Countries along the Belt and Road. J Glob Econ 6: 284. doi: 10.4172/2375-4389.1000284

is the basic form of the time-varying model, which is the parameter to be estimated to reflect the change of "inefficiency" over time. When it is zero, it means "inefficiency" The level does not change with time, when not zero, indicating that the level of inefficiency changes over time, known as the time-varying model.

\section{An extended model}

When using the stochastic frontier model, Armstrong (2007) argues that the gravity model should include only core variables such as the economic development status, distance, boundaries and language of the two investors that will not change in a short period of time. And the human-made FTA, Political and legal system environment and other factors into the non-efficiency model as shown in Table 1.

The estimated inefficiency over time is 0.018 and the $\mathrm{P}$ value is 0.045 . By the significance test at the level of $10 \%$, the OFDI of China over the Belt and Road countries shows obvious changes over time. Therefore, the stochastic frontier model should be chosen Change the model [3].

Based on the above idea, the stochastic frontal gravitation model (6) is expanded based on (1). The specific equation is as follows:

$\ln$ OFDI $_{i j t}=\beta_{0}+\beta_{1} \ln G D P_{j t}+\beta_{2} \ln G D P_{i t}+\beta_{3} \ln D_{i s t}+\beta_{i j} \operatorname{Lang}_{i j}+\beta_{5}$ Contig $_{i j}+\beta_{6}$ Inter $_{i t}+V_{i t}-U_{i t}$

In the equation, like the classical gravity model, the explanatory variables $\ln$ OFDI $I_{i j t}$,epresent the actual investment flows of China in the t-th period. The explanatory variables are GDP ${ }_{i p} G D P_{i p}$ Dist $_{i p}$ Lang $_{i i^{3}}$ Contig $_{i j}$ and Inter $r_{i t}$ where $\mathrm{j}$ stands for China and i stands for 46 countries along the Belt and Road; $\left(\mathrm{V}_{\mathrm{it}}-\mathrm{U}_{\mathrm{it}}\right)$ is a random disturbance item, which is a noise error hit by uncontrollable factors (such as statistical error) in the economic system and obeys a symmetrical normal distribution. $U_{i t}$ For investment inefficiency, subject to a semi-normal distribution. $e^{-U_{i t}}$ reflect the level of investment efficiency. Construct the following inefficient investment equation:

$$
U_{i t}=\gamma_{0}+\gamma_{1} \text { Open }_{i t}+\gamma_{2} W_{T}+\gamma_{3} F_{T A}+\gamma_{4} \operatorname{Cofe}_{i t}+\gamma_{5} \operatorname{Cotr}_{i t}+v_{i t}
$$

\section{Variable explanation and data source}

This paper selects the data of 46 countries in the countries along the "One Belt and Road" for a time span of 2006-2015. Due to the serious lack of data in some countries, the data were not selected as samples. For example, Latvia, Lithuania, Bahrain, Macedonia, and Montenegro were not included [4]. Estimates and substitutions of the arithmetic mean and regression of very few missing data were used as shown in Table 2 .

\section{The Empirical Results and Analysis}

\section{Model parameter estimation}

The stata 14.0 statistical analysis software was used to estimate the parameters of model (6) and (7). Using Hausman test, the significant $\mathrm{P}\left(\right.$ Prob $\left.>\mathrm{chi}^{2}=0.1080\right)$ was far greater than $5 \%$. So accept the original

\begin{tabular}{|c|c|c|c|c|c|c|c|c|}
\hline \multicolumn{5}{|c|}{ Time Invariant Model } & \multicolumn{4}{|c|}{ Time-Varing Model } \\
\hline Var & Coef & SE & $\mathbf{Z}$ & $\mathbf{P}$ & Coef & SE & $\mathbf{Z}$ & $\mathbf{P}$ \\
\hline $\ln G D P_{j t}$ & 1.675 & 0.1436 & 11.74 & $0.000^{* * *}$ & 1.451 & 0.2408 & 6.03 & $0.000^{* * *}$ \\
\hline $\ln G D P_{t t}$ & 0.51 & 0.0915 & 5.58 & $0.000^{* * *}$ & 0.519 & 0.0914 & 5.69 & $0.000^{* * *}$ \\
\hline $\ln$ ist $_{i j}$ & -2.497 & 0.5477 & -4.56 & $0.000^{* * *}$ & -2.522 & 0.5383 & -4.69 & $0.000^{* * *}$ \\
\hline Lang $_{i j t}$ & 1.519 & 0.7712 & 1.97 & $0.049^{*}$ & 1.548 & 0.7859 & 1.97 & $0.049^{* * *}$ \\
\hline Contig $_{i j}$ & 0.448 & 0.4442 & 1.01 & 0.313 & 0.455 & 0.4408 & 1.03 & 0.302 \\
\hline Internet $_{i t}$ & 0.013 & 0.156 & 0.86 & 0.391 & 0.014 & 0.0156 & 0.9 & 0.369 \\
\hline cons & 14.202 & 4.8895 & 2.9 & $0.004^{* * *}$ & 16.32 & 5.1583 & 3.16 & $0.002^{*}$ \\
\hline$\sigma^{2}$ & 5.3049 & 2.1506 & - & - & 4.836 & 1.9687 & - & - \\
\hline$\sigma_{u}^{2}$ & 3.9484 & 2.1503 & - & - & 3.486 & 0.1149 & - & - \\
\hline$\sigma_{v}^{2}$ & 1.3565 & 0.1009 & - & - & 1.351 & 0.1005 & - & - \\
\hline$\gamma$ & 0.7443 & 0.1048 & - & - & 0.721 & 0.1149 & - & - \\
\hline$\eta$ & & & - & - & 0.018 & 0.1531 & 1.16 & 0.045 \\
\hline
\end{tabular}

Table 1: Inefficient time-varying estimation results.

\begin{tabular}{|c|c|}
\hline variable & Variable Explanation \\
\hline OFDI $I_{i t}$ & China's direct investment flows to the "Belt and Road" countries \\
\hline$G D P_{j t}$ & China's economic strength, it is expected to have a positive correlation with OFDI. \\
\hline$G D P_{i t}$ & The economy of the host country reflects the market capacity of the host country and is therefore expected to have positive correlation with OFDI. \\
\hline Dist $_{i j}$ & The geographical distance between the capital cities or major cities of both trade is expected to be negatively related to OFDI. \\
\hline Lang $_{i j}$ & Both languages can reduce investment costs; the same value for the official language is 1 , otherwise 0 . \\
\hline Contig $_{i j}$ & $\begin{array}{l}\text { Whether there is a common border, adjacent to the two countries is conducive to reducing investment costs, is expected to have a positive correlation } \\
\text { with OFDI; Host country Internet coverage, reflecting the state of infrastructure construction }\end{array}$ \\
\hline Inte ${ }_{\text {rit }}$ & The dependence of the host country on foreign trade is expected to be positively correlated with OFDI \\
\hline \multicolumn{2}{|l|}{ Open $_{i t}$} \\
\hline$W T O_{i t}$ & WTO accession is conducive to investment in the host country's direct investment, is expected to be positively correlated with OFDI. \\
\hline$F T A_{i t}$ & the establishment of free trade area value of 1 , or 0. \\
\hline Gofe $_{i t}$ & The government efficiency of the GHI, political stability, the mean value of civic discourse and accountability scores. \\
\hline Cotr $_{\text {it }}$ & The average of the scores of corruption control, regulatory quality and legal rules of the global governance index. \\
\hline$L^{2 a p o}{ }_{i t}$ & The labor supply situation in the host country. \\
\hline
\end{tabular}

Table 2: Variable selection. 
Citation: Jiang XB, Liu LM (2018) China's Direct Investment Efficiency toward the Countries along the Belt and Road. J Glob Econ 6: 284. doi: 10.4172/2375-4389.1000284

Page 3 of 5

hypothesis, the final choice of random effects model. The main influencing factors of the "inefficiency" model of investment are further tested and the results show that $\gamma=0.937$. The $5 \%$ significance test shows that the inefficient investment is the main factor that hinders China's outward direct investment. Table 3 explains the results of the parameter estimation for the random frontier gravitational model (6) are as follows:

The stochastic frontier expression is as follows:

$\operatorname{lnOFDI} I_{i j t}=10.381+1.620 \ln G D P_{j t}+0.605 \ln G D P_{i t}-2.305 \ln D i s t_{i j}+1.907$ Lang $_{i j}+0.991$ Contig $_{i j}+0.011$ Internet $_{i t}+V_{i t}-U_{i t}$

In the above expression. $\beta_{1}$ Shows that there is a significant and positive correlation between China's state of economic development and direct investment in the "Belt and Road" country, with a correlation coefficient of 1.620 . The estimates $\beta_{2}$ indicate that the economy of the host country is significantly and positively correlated with its direct investment, and the correlation coefficient Is 0.605 . The better a country's economy develops, the easier it is for traumatic direct investment and the easier it is to attract foreign direct investment $[5,6]$. The estimated value $\beta_{3}$ shows that China's direct investment in the host country is negatively correlated with the distance between the two countries, with a correlation coefficient of -2.305 . Both countries Geographical distance is the most important part of the investment resistance. Taking into account that most countries along the Belt and Road are landlocked countries, the calculation of the distance between the capitals or major cities of the two countries should be taken into account [7]. The estimates $\beta_{4}$ indicate whether the investors have a common official language and the correlation coefficient is 1.907 . The common official language can promote cultural exchanges and increase investment. The estimated values $\beta_{5}$ indicate that whether the host country has a common border with China is positively correlated with our investment in China, but the correlation has not reached a significant level. The estimates $\beta_{6}$ indicate the host country's infrastructure and the volume of investment by our country Positive correlation did not reach significant level.

Table 4 shows the results of the inefficient investment model are as follows:

According to the estimation results of the above parameters, we can get the expression of inefficient investment model:

$U_{i t}=2.376-0.0145 \quad$ Open $_{i t}-0.006 W_{T O}-0.1719$ FTA $_{i t}+0.0011$ Gofe $_{i t}{ }^{-}$ 0.021 Cotr $_{i t}-v_{i t .}$

\begin{tabular}{|c|c|}
\hline Var & InGDP \\
\hline Coef & 1.62 \\
\hline SE & 0.158 \\
\hline Z & 10.23 \\
\hline P & $0.000^{* * *}$ \\
\hline
\end{tabular}

\begin{tabular}{|c|c|}
\hline InGDP $_{\text {itt }}$ & In Dist $_{i j}$ \\
\hline 0.605 & -2.305 \\
\hline 0.148 & 0.726 \\
\hline 4.1 & -3.18 \\
\hline $0.000^{\star \star *}$ & $0.001^{\text {** }}$ \\
\hline
\end{tabular}

\section{Investment efficiency analysis}

The estimation of investment efficiency is an important application of stochastic frontier model. After completing the above analysis of selected samples, this paper focuses on the analysis of Southeast Asia as shown in the Table 5 .

The efficiency of OFDI reflects the deviation of the investment status from the frontier of investment. The lower the investment efficiency, the higher the deviation and the greater the investment potential. China's investment efficiency in the countries along the "Belt and Road" is generally low, but its overall upward trend [2,8-10]. Only when the investment efficiency of a few countries or regions exceeds 0.8 , most of the countries of the investment efficiency is relatively low, the investment efficiency of most countries or regions is less than 0.2 Note On the whole, China's foreign direct investment in most countries needs to be further explored, and there is great potential for investment [11].

In terms of regional distribution, there are significant differences in investment efficiency between Southeast Asia, South Asia, Central Asia East Asia, Central and Eastern Europe and West Asia and North Africa. Taking 2015 as an example, China has the highest level of investment efficiency in West Asia and North Africa. Among the 15 sample countries, 6 have investment efficiency of over 0.5, accounting for 40\%; followed by Southeast Asia, Central Asia, East Asia and Central and Eastern Europe; Investment levels in countries or regions are low $[12,13]$.

From an analysis of the national investment efficiency of ASEAN countries from 2006 to 2015, it is obvious that there is a marked polarization of investment efficiency among ASEAN countries $[14,15]$. Investment efficiency in Singapore, Indonesia, Cambodia and Laos has been maintained for the past decade Higher levels, no significant changes, while Malaysia, the Philippines and Vietnam and other countries are hovering at the inefficient interval level; China's investment in ASEAN countries have steadily increased the efficiency of investment, the most obvious is Cambodia, the other Philippines investment efficiency Not rise or fall.

\section{Conclusion}

This article draws the following conclusion:

(1) Under the strategy of "One Belt, One Road", while seeking market and resources in our country, the host country's economic scale, resource endowments and infrastructure have a significant impact on the growth of China's foreign direct investment. The host country and

Note: ${ }^{* * *}$, signifies the level of $1 \%$

Table 3: Stochastic frontier model coefficient estimation results.

\begin{tabular}{|c|c|c|c|c|c|c|}
\hline Var & Open $_{i t}$ & $W T O_{i t}$ & $F T A_{i t}$ & Gofe $_{i t}$ & Cotr $_{i t}$ & cons \\
\hline Cofe & -0.0145 & -0.006 & -0.1719 & 0.0011 & -0.021 & 2.367 \\
\hline SE & 0.0048 & 0.1013 & 0.0873 & 0.0069 & 0.0075 & 0.0887 \\
\hline$Z$ & -3.05 & -0.01 & 1.97 & 0.15 & 2.85 & 2.67 \\
\hline$P$ & $0.001^{* * *}$ & 0.795 & $0.049^{\star * *}$ & 0.882 & $0.005^{\star \star \star}$ & $0.008^{* * *}$ \\
\hline
\end{tabular}

Table 4: Non-efficiency model estimation results. 
Citation: Jiang XB, Liu LM (2018) China's Direct Investment Efficiency toward the Countries along the Belt and Road. J Glob Econ 6: 284. doi: $10.4172 / 2375-4389.1000284$

Page 4 of 5

\begin{tabular}{|c|c|c|c|c|c|c|c|c|c|c|c|}
\hline & Nation & 2006 & 2007 & 2008 & 2009 & 2010 & 2011 & 2012 & 2013 & 2014 & 2015 \\
\hline \multirow{10}{*}{$\begin{array}{l}\text { Southeast } \\
\text { Asia }\end{array}$} & Malaysia & 0.043 & 0.046 & 0.048 & 0.051 & 0.053 & 0.056 & 0.059 & 0.062 & 0.065 & 0.068 \\
\hline & Singapore & 0.531 & 0.537 & 0.542 & 0.547 & 0.553 & 0.558 & 0.563 & 0.569 & 0.574 & 0.579 \\
\hline & Indonesia & 0.67 & 0.674 & 0.678 & 0.683 & 0.687 & 0.691 & 0.695 & 0.699 & 0.703 & 0.707 \\
\hline & Brunei & 0.027 & 0.029 & 0.031 & 0.033 & 0.035 & 0.037 & 0.039 & 0.041 & 0.043 & 0.046 \\
\hline & Philippines & 0.045 & 0.048 & 0.05 & 0.053 & 0.056 & 0.058 & 0.061 & 0.064 & 0.068 & 0.056 \\
\hline & Thailand & 0.162 & 0.168 & 0.173 & 0.178 & 0.183 & 0.188 & 0.194 & 0.199 & 0.205 & 0.211 \\
\hline & Cambodia & 0.76 & 0.764 & 0.767 & 0.77 & 0.774 & 0.777 & 0.78 & 0.783 & 0.787 & 0.79 \\
\hline & Laos & 0.678 & 0.682 & 0.686 & 0.69 & 0.695 & 0.699 & 0.703 & 0.707 & 0.711 & 0.715 \\
\hline & Myanmar & 0.397 & 0.403 & 0.409 & 0.415 & 0.421 & 0.427 & 0.433 & 0.439 & 0.445 & 0.451 \\
\hline & Vietnam & 0.076 & 0.08 & 0.083 & 0.087 & 0.091 & 0.095 & 0.098 & 0.102 & 0.107 & 0.111 \\
\hline \multirow[t]{6}{*}{ South Asia } & Sri Lanka & 0.098 & 0.102 & 0.106 & 0.111 & 0.115 & 0.119 & 0.123 & 0.128 & 0.132 & 0.137 \\
\hline & Bengal & 0.013 & 0.014 & 0.016 & 0.017 & 0.018 & 0.019 & 0.021 & 0.022 & 0.024 & 0.025 \\
\hline & Pakistan & - & 0.283 & 0.289 & 0.295 & 0.301 & 0.307 & 0.313 & 0.319 & 0.325 & 0.331 \\
\hline & India & 0.031 & 0.033 & 0.035 & 0.037 & 0.039 & 0.041 & 0.044 & 0.046 & 0.049 & 0.051 \\
\hline & Afghanistan & 0.049 & 0.051 & 0.054 & 0.057 & 0.06 & 0.063 & 0.066 & 0.069 & 0.072 & 0.06 \\
\hline & Nepal & - & 0.006 & 0.007 & 0.007 & 0.008 & 0.009 & 0.009 & 0.01 & 0.011 & 0.012 \\
\hline \multirow{6}{*}{$\begin{array}{l}\text { Central Asia } \\
\text { East Asia }\end{array}$} & Mongolia & 0.098 & 0.102 & 0.106 & 0.11 & 0.115 & 0.119 & 0.123 & 0.128 & 0.132 & - \\
\hline & Uzbekistan & 0.117 & 0.122 & 0.126 & 0.13 & 0.135 & 0.14 & 0.144 & 0.149 & 0.154 & 0.159 \\
\hline & Tajikistan & 0.348 & 0.354 & 0.361 & 0.367 & 0.373 & 0.379 & 0.385 & 0.391 & 0.397 & 0.403 \\
\hline & Kazakhstan & 0.271 & 0.277 & 0.283 & 0.289 & 0.295 & 0.301 & 0.307 & 0.313 & - & - \\
\hline & Kyrgyzstan & 0.386 & 0.392 & 0.398 & 0.404 & 0.41 & 0.416 & 0.422 & 0.428 & 0.434 & 0.44 \\
\hline & Turkmenistan & - & 0.505 & 0.51 & 0.515 & 0.521 & 0.526 & 0.532 & 0.537 & 0.542 & 0.524 \\
\hline \multirow{8}{*}{$\begin{array}{l}\text { Central and } \\
\text { Eastern } \\
\text { Europe }\end{array}$} & Romania & 0.07 & 0.073 & 0.076 & 0.08 & 0.083 & 0.087 & 0.09 & 0.094 & 0.098 & 0.102 \\
\hline & Czech Republic & 0.081 & 0.084 & 0.088 & 0.091 & 0.095 & 0.099 & 0.103 & 0.107 & 0.111 & 0.096 \\
\hline & Poland & 0.065 & 0.073 & 0.076 & 0.08 & 0.083 & 0.087 & 0.091 & 0.094 & 0.098 & 0.102 \\
\hline & Bulgaria & - & - & - & - & 0.377 & 0.383 & 0.389 & 0.395 & 0.401 & 0.407 \\
\hline & Croatia & - & 0.005 & 0.006 & 0.006 & 0.007 & 0.008 & 0.008 & 0.009 & 0.01 & 0.007 \\
\hline & Belarus & - & - & 0.14 & 0.144 & 0.149 & 0.154 & 0.159 & 0.164 & 0.169 & 0.174 \\
\hline & Ukraine & 0.012 & 0.013 & 0.014 & 0.016 & 0.017 & 0.018 & 0.019 & 0.021 & 0.022 & 0.017 \\
\hline & Hungary & 0.139 & 0.144 & 0.149 & 0.154 & 0.159 & 0.164 & 0.169 & 0.174 & 0.179 & 0.185 \\
\hline \multirow[t]{3}{*}{ West Asia } & ARE & 0.659 & 0.664 & 0.668 & 0.673 & 0.677 & 0.681 & 0.685 & 0.69 & 0.694 & 0.698 \\
\hline & Georgia & 0.744 & 0.748 & 0.751 & 0.755 & 0.758 & 0.762 & 0.765 & 0.768 & 0.772 & 0.775 \\
\hline & Israel & 0.048 & 0.05 & 0.053 & - & 0.058 & 0.061 & 0.064 & 0.067 & 0.07 & 0.074 \\
\hline \multirow[t]{13}{*}{ North Africa } & Lebanon & - & - & - & - & 0.006 & - & - & 0.007 & 0.008 & - \\
\hline & Oman & 0.076 & 0.079 & - & - & 0.09 & 0.093 & 0.097 & 0.101 & 0.105 & 0.109 \\
\hline & Qatar & 0.171 & 0.176 & 0.181 & 0.187 & 0.192 & 0.197 & 0.203 & 0.208 & 0.214 & 0.219 \\
\hline & Iran & 0.64 & 0.644 & 0.649 & 0.653 & 0.658 & 0.662 & 0.667 & 0.671 & 0.675 & 0.658 \\
\hline & Iraq & 0.07 & 0.073 & 0.077 & 0.08 & 0.083 & 0.087 & 0.091 & 0.095 & 0.099 & 0.103 \\
\hline & Egypt & 0.438 & 0.443 & 0.449 & 0.455 & 0.461 & 0.467 & 0.473 & 0.479 & 0.484 & 0.501 \\
\hline & Jordan & & 0.012 & 0.013 & 0.013 & 0.015 & 0.016 & 0.017 & 0.018 & 0.019 & 0.021 \\
\hline & Turkey & 0.109 & 0.113 & 0.117 & 0.122 & 0.126 & 0.131 & 0.135 & 0.14 & 0.145 & 0.15 \\
\hline & Kuwait & 0.133 & 0.137 & 0.142 & 0.147 & 0.152 & 0.156 & - & - & 0.171 & 0.177 \\
\hline & Yemen & 0.495 & 0.501 & 0.506 & 0.512 & 0.517 & 0.523 & 0.528 & 0.534 & 0.539 & 0.517 \\
\hline & Azerbaijan & 0.017 & - & - & 0.021 & 0.023 & 0.024 & 0.026 & 0.028 & 0.029 & 0.031 \\
\hline & Saudi Arabia & 0.539 & 0.544 & 0.549 & 0.555 & 0.56 & 0.565 & 0.57 & 0.576 & 0.581 & 0.586 \\
\hline & Russia & 0.638 & 0.643 & 0.647 & 0.652 & 0.656 & 0.661 & 0.665 & 0.67 & 0.674 & 0.678 \\
\hline
\end{tabular}

Table 5: Estimates of national investment efficiency along the belt and road.

China have common borders or official languages, Direct foreign direct investment has a significant positive impact, while bilateral geographic distance between trade and direct investment also showed a positive correlation. However, with the development of the transport industry and the facilitation of international settlements, the impact of such factors on direct investment will gradually diminish.

(2) Conflicts in the internal political environment in the host country and poor supervision of corruption will increase the loss of investment efficiency. The political situation in Southeast Asia is relatively stable and the loss of efficiency is small. Dependence on foreign direct investment will be increased due to the increase of trade dependence, and the efficiency of investment in China will be enhanced. In addition, As most countries along the Belt and Road are WTO members, the impact of this factor on investment efficiency is not significant. However, the signing of a bilateral investment agreement with China by the host country will promote China's investment efficiency. The efficiency of China's investment in ASEAN also stems from Free Trade Zone. FTAs under negotiation and research, such as the negotiating FTAs such as China-New Zealand, China-Israel and the China-Mongolia-China-Bangladesh FTA under study, will enhance China's foreign direct investment.

At this stage, the efficiency of FDI in our country is still low. Therefore, we should carefully scrutinize the possible loss of efficiency brought by the host country factor, avoid the risk of loss of efficiency 
Citation: Jiang XB, Liu LM (2018) China's Direct Investment Efficiency toward the Countries along the Belt and Road. J Glob Econ 6: 284. doi: $10.4172 / 2375-4389.1000284$

Page 5 of 5

of overseas investment, evaluate the performance of investment, and according to the actual situation of the investing country. The situation weighs out foreign direct investment decisions and rationally plans macro strategic layout.

\section{References}

1. Aigner D, Knox LCA, Schmidt P (1977) Formulation and Estimation of Stochastic Frontier Production Function Models. Journal of Econometrics 6: 21-37.

2. Chai Q, Hu TY (2012) Study on the Trade Effect of China's Foreign Direct Investment - Based on the Investigation of the Difference between the Investment of ASEAN and European Union. World Economic Research 6: 64-9.

3. Dunning J, Lundan S (1993) Multinational Enterprises and the Global Economy Wokingham. Addison Wesley, pp: 91-97.

4. Kanenga H (2016) One Belt One Road Strategy in China and Economic Development in the Concerning Countries. Journal of Xian Jiaotong University 2: $10-14$

5. Hai YL, Ying KT, Xiao LC, Joanna P (2017) The Determinants of Chinese Outward FDI in Countries Along One Belt One Road. University of International Business and Economics 53: 1374-87.

6. Wang F (2016) Prospects and Risk Prevention of China's Outbound Investment under the Belt and Road Initiative. Economic Forum 7: 33-36.
7. Yanying $\mathrm{H}$, Thomas BF, He X (2016) The stakeholder analysis for SEA of Chinese foreign direct investment: the case of 'One Belt, One Road' initiative in Pakistan. Journal of Impact Assessment and Project Appraisal 35: 158-171.

8. Huang Y (2016) Understanding China's Belt and Road Initiative: Motivation, framework and assessment. China Economic Review 40: 314-321.

9. Liu W, Dunford M (2016) Inclusive globalization: Unpacking China's belt and road initiative. Area Development and Policy 1: 323-340.

10. Li LB, Hu JL (2012) Ecological total-factor energy efficiency of regions in China. Energy Policy 46: 216-224.

11. Ogutçu M (2002) Foreign direct investment and regional development: sharing experiences from Brazil, China, Russia and Turkey. In International Conference on Regional Development and Foreign Investment in Brazil.

12. Bellak C, Leibrecht M, Damijan JP (2009) Infrastructure endowment and corporate income taxes as determinants of foreign direct investment in Central and Eastern European countries. The World Economy 22: 267-290.

13. Djankov S, Miner S (2016) China's Belt and Road Initiative: motives, scope and challenges. Peterson Institute for International Economics.

14. Liu W, Dicken P (2006) Transnational corporations and 'obligated embeddedness': Foreign direct investment in China's automobile industry. Environment and Planning A 38: 1229-1247.

15. Arase D (2015) China's two silk roads initiative: What it means for Southeas Asia. Southeast Asian Affairs, pp: 5-45. 